\title{
Clinical and Economic Impact of Widespread Rapid Testing to Decrease SARS-CoV-2 Transmission
}

\author{
A. David Paltiel, PhD \\ Amy Zheng, BA \\ Paul E. Sax, MD
}

Author affiliations: From the Public Health Modeling Unit, Yale School of Public

Health (ADP), New Haven, CT; the Division of Infectious Diseases, Brigham and

Women's Hospital (PES), Boston, MA; and Harvard Medical School (AZ, PES), Boston, MA.

\section{Corresponding Author:}

A. David Paltiel, $\mathrm{PhD}$

Yale School of Public Health

60 College Street, New Haven CT 06510

(203) 436-4081

david.paltiel@yale.edu

Word Counts: Main text: 2,869; Abstract: 275

Disclosures: None. 


\begin{abstract}
Background: The value of frequent, rapid testing to reduce community transmission of SARS-CoV-2 is poorly understood.

Objective: To define performance standards and predict the clinical, epidemiological, and economic outcomes of nationwide, home-based, antigen testing.
\end{abstract}

Design: A simple compartmental epidemic model estimated viral transmission, clinical history, and resource use, with and without testing.

Data Sources: Parameter values and ranges informed by Centers for Disease Control guidance and published literature.

Target Population: United States population.

Time Horizon: 60 days.

Perspective: Societal. Costs include: testing, inpatient care, and lost workdays.

Intervention: Home-based SARS-CoV-2 antigen testing.

Outcome Measures: Cumulative infections and deaths, numbers isolated and/or hospitalized, and total costs. 
Results of Base-Case Analysis: Without a testing intervention, the model anticipates 15 million infections, 125,000 deaths, and $\$ 10.4$ billion in costs ( $\$ 6.5$ billion inpatient; $\$ 3.9$ billion lost productivity) over a 60-day horizon. Weekly availability of testing may avert 4 million infections and 19,000 deaths, raising costs by $\$ 21.5$ billion. Lower inpatient outlays ( $\$ 5.9$ billion) would partially offset additional testing expenditures ( $\$ 12.0$ billion) and workdays lost ( $\$ 13.9$ billion), yielding incremental costs per infection (death) averted of $\$ 5,400(\$ 1,100,000)$.

Results of Sensitivity Analysis: Outcome estimates vary widely under different behavioral assumptions and testing frequencies. However, key findings persist across all scenarios: large reductions in infections, mortality, and hospitalizations; and costs per death averted roughly an order of magnitude lower than commonly accepted willingnessto-pay values per statistical life saved (\$5-17 million).

Limitations: Analysis restricted to at-home testing and limited by uncertainties about test performance.

Conclusion: High-frequency home testing for SARS-CoV-2 using an inexpensive, imperfect test could contribute to pandemic control at justifiable cost and warrants consideration as part of a national containment strategy.

\section{Primary Funding Sources:}


medRxiv preprint doi: https://doi.org/10.1101/2021.02.06.21251270; this version posted February 8, 2021. The copyright holder for this preprint (which was not certified by peer review) is the author/funder, who has granted medRxiv a license to display the preprint in perpetuity.

It is made available under a CC-BY-ND 4.0 International license .

Dr. Paltiel was supported by grant R37DA015612 from the National Institute on Drug Abuse of the National Institutes of Health.

Dr. Sax was supported by grant R01AI042006 from the National Institute of Allergy and Infectious Diseases of the National Institutes of Health. 


\section{INTRODUCTION}

Previous research identified social distancing (masks, de-densification, lockdowns), large-scale diagnostic testing, and vaccination as essential elements of a coordinated plan to contain the COVID-19 pandemic. One strategy receiving less formal attention is the high-frequency use of low-cost, rapid, home-based antigen testing for SARS-CoV-2 with self-enforced isolation for those who obtain a positive result. ${ }^{1-5}$ Advocates point to the potential advantages: prevention by isolation; focusing on "infectiousness" rather than "infection"; and reducing strain on laboratories that must conduct viral polymerase chain reaction (PCR)-based diagnostic testing. ${ }^{6-8}$ Critics note that such an approach risks poor uptake and adherence, frequent false negatives leading to unfounded reassurance, and frequent false positives resulting in needless isolation and lost work productivity. ${ }^{9}$

We seek to formalize this discussion by capturing both the promise and the concerns in the structure of a mathematical model. We aim to identify the circumstances that would have to prevail - about the accuracy of antigen testing, about the cost of both initial and confirmatory tests, about the lost workdays arising from isolation (both true and false positives) and disease, and about individual behavior - for such an intervention to be of clinical, economic, epidemiologic, and policy interest. 


\section{METHODS}

\section{Study Design}

We adapted a simple compartmental epidemic model (Appendix Figure A1) to capture the essential elements of a population-wide, home-based testing program to detect, isolate, and contain contagious SARS-CoV-2. Features we sought to portray included: the epidemiology of infection; the natural history of COVID-19 illness; the behavioral response to test availability, test results, and isolation; and the financial consequences of testing, hospitalization, and lost workdays arising from illness, isolation, and (potentially incorrect) test findings. A spreadsheet implementation of the model permitted us to vary critical input data parameters and to examine how different test performance attributes (e.g., frequency, sensitivity, specificity, cost), different behavioral responses (e.g., acceptance of antigen testing, willingness to self- isolate, propensity to abandon isolation), and different epidemiological scenarios would translate into both health outcomes (e.g., tests administered, true/false positives, new infections, person-days requiring isolation, hospitalizations, and deaths) and economic performance (e.g., testing costs, inpatient costs, lost productivity, and cost-effectiveness). Given the rapid spread of infection and the speed of new advances, we adopted a short, 60-day planning horizon.

Input data (Appendix Table A1) were obtained from published sources, adhering whenever possible to planning scenarios and data guidance for modelers from the Centers for Disease Control and Prevention (CDC) and the Office of the Assistant Secretary for 
Preparedness and Response (ASPR). ${ }^{10-20}$ Because our aim was to identify the circumstances under which widespread, rapid home testing might warrant inclusion as part of a national containment strategy, we deliberately tipped the scales to portray the intervention in a less favorable light, choosing false-positive and false-negative rates at the upper end of the plausible range, inflating costs, and exaggerating levels of noncompliance with recommended protocols. To provide context for our estimates of the incremental cost per death averted, we followed the guidance of the Office of the Assistant Secretary for Planning and Evaluation and applied the value of a statistical life (VSL), a benchmark of the societal willingness to pay for reductions in mortality risks. ${ }^{10}$ Here again, we erred on the side of conservatism, adopting the lower bound value $(\$ 5.3$ million) from the recommended range (central estimate $=\$ 11.5$ million; upper bound $=$ $\$ 17.3$ million).

\section{Compartmental Model}

We made two notable changes to the traditional "susceptible-exposed-infected-removed" (or "SEIR") compartmental modeling framework (Appendix Figure A1). First, we separated the single "infected" compartment into four sub-compartments: "asymptomatic", "mild/moderate", "severe", and "critical". This permitted us to capture more fully the natural history, epidemiology, and resource use associated with progressive COVID-19. Second, we distinguished between epidemiologically "active" and "removed" individuals. In "active" compartments, we assumed that individuals interact in ways that permit infectious contact and transmission of SARS-CoV-2; in 
"removed" compartments, no transmission was possible. We provided two pathways into the "removed" compartments. Individuals with "severe" and "critical" infection were removed by virtue of their advanced COVID-19 symptoms and hospitalization. (A userdefined variable also permitted some fraction of individuals with "mild/moderate" symptoms to self-isolate.) As described in greater detail in the next section, testing offered a second avenue to removal.

We considered different background epidemic severities. We assumed baseline effective reproduction number $R_{t}=1.3$ and explored values ranging from 0.9 to 2.1 in sensitivity analysis. As detailed in the Appendix, we assumed that $60 \%$ of infections would produce symptoms, that $10 \%$ of those with symptoms would advance to severe disease, and that $5 \%$ of those with severe disease would advance to critical illness. Base occupancy times for persons progressing to more advanced illness were $3,10,6$, and 4 days in the “exposed”, “asymptomatic”, “mild/moderate”, and "severe” states, respectively. We used mortalities of $1 \%, 5 \%$, and $15 \%$ from the "mild/moderate", "severe", and "critical" states.

\section{Performance of Testing}

Regular opportunities to be tested for SARS-CoV-2 contagion were offered to persons in the active "uninfected", "exposed", "asymptomatic", and "mild/moderate" compartments. We reviewed the data on the performance of antigen testing and found sensitivity estimates ranging from a low of $41.2 \%$ to a high of $100 \%$ and specificities from $97 \%$ to 
$99.9 \% .^{7,21-27}$ We then focused our estimates on cases when testing was accompanied by either a low cycle threshold (high titers of virus) or the ability to isolate replicationcompetent virus, as these cases represented people in the most transmissible stage of COVID-19 and excluded those in the recovery phase who might still have positive PCRs. ${ }^{13,28-29}$ While some studies described antigen sensitivity as exceeding $90 \%$ under these circumstances, we deliberately lowered our base case sensitivity assumption to $80 \%$ to reflect less-than-optimal testing characteristics in the home setting. We did not consider how repeat testing might increase this sensitivity. Similar motivations led us to adopt a lower-bound value of $95 \%$ for test specificity, exploring even lower values $(90 \%)$ in sensitivity analysis. ${ }^{7}$ We examined weekly testing in the base case but considered frequencies ranging from daily to once every 15 days in sensitivity analysis.

To capture both the costs and the potential delays of confirmatory testing, we assumed that the shipment of testing kits to households would include a swab for obtaining a PCR test, to be self-collected at home and sent to a central laboratory in the event of a positive rapid test result. Individuals whose initially false-positive result had led them to adhere to recommended isolation protocols were assumed to return to the active population after a 3-day delay. ${ }^{30}$ (This assumption ignored the small possibility of repeatedly false-positive confirmatory test findings.) 
Finally, we assumed that, in the absence of disease progression, successful isolation of infected persons for 10 days would lead to recovery and non-infectious return to the "active" population.

\section{Behavioral response}

To account for concerns about individual willingness to adhere to testing and isolation protocols, we adopted a highly pessimistic view of the behavioral response to the testing intervention. In the base case, we assumed that: a) only $50 \%$ of individuals would elect to make use of the test kits provided to them; b) only $50 \%$ of individuals receiving a positive test finding would respond by isolating themselves as instructed; and c) even among those who did initially isolate, $20 \%$ each day would abandon isolation and return to the "active" population against recommended guidance. We further assumed that only $50 \%$ of persons exhibiting moderate symptoms of COVID-19 would elect to self-isolate, in the absence of positive test finding. Here again, we assumed that even among symptomatic individuals who did initially elect to isolate, $20 \%$ would abandon isolation each day.

Recognizing the uncertainties surrounding these assumptions, we examined a spectrum of alternative behavioral response scenarios - including an even-more-pessimistic "worst case" - in sensitivity analysis (Table 1). 


\section{Economic outcomes}

We assigned 3 categories of cost: testing, inpatient, and lost productivity. Here again, we chose values that would deliberately bias the analysis against the intervention: exaggerating the costs of testing and lost workdays, and under-stating the costs of hospitalization. Testing costs included both the initial testing kit ( $\$ 5$, range $\$ 1-\$ 10)$ and the confirmatory test (base $\$ 20$, range $\$ 5-\$ 50)$. The current price of a single over-thecounter antigen test for SARS-CoV-2 is roughly $\$ 25$ or more, a figure that includes a substantial markup for both the manufacturer and the retailer and that offers no quantity discount. ${ }^{17}$ Experience with other infectious diseases (malaria, for example) suggests that high-volume, paper-strip-based antigen tests can be obtained at wholesale prices as low as $\$ 0.20$ per unit for government-based purchase orders of the magnitude being considered here. ${ }^{18}$ The initial test costs were assigned on an "intent-to-treat" basis. In other words, mailing test kits to someone's home incurred the cost, whether or not the individual chose to use the test. Inpatient costs were assigned per day with severe illness $(\$ 1,000)$ or critical illness $(\$ 2,500)$. Every day spent in the hospital or in isolation regardless of whether isolation was the result of a true- or a false-positive finding - was treated as a day of lost productivity, which we assigned a cost of $\$ 180$, based on the daily per capita gross domestic product. ${ }^{19,20}$

\section{Role of Funding Source}


medRxiv preprint doi: https://doi.org/10.1101/2021.02.06.21251270; this version posted February 8, 2021. The copyright holder for this preprint (which was not certified by peer review) is the author/funder, who has granted medRxiv a license to display the preprint in perpetuity.

It is made available under a CC-BY-ND 4.0 International license .

This work was supported by awards from the National Institute on Drug Abuse (R37

DA015612) and the National Institute of Allergy and Infectious Diseases

(R01AI042006), both of the National Institutes of Health. The funding sources had no

role in the design, analysis, or interpretation of the study, the writing of the manuscript, or in the decision to submit the manuscript for publication. 


\section{RESULTS}

\section{Base case}

In the absence of a testing intervention, the model anticipates 15 million infections, 125,000 deaths, and $\$ 10.4$ billion in costs ( $\$ 6.5$ billion inpatient; $\$ 3.9$ billion lost productivity) over a 60-day horizon (Table 2). Weekly home testing under base case assumptions could reduce infections to 11 million and deaths to 106,000. Lower inpatient costs ( $\$ 5.9$ billion) would partially offset additional outlays for testing ( $\$ 12.0$ billion) and greater lost workdays ( $\$ 13.9$ billion). Although testing and isolation would increase the total number of workdays lost (from 21.4 million to 77.4 million days), individuals could expect to be isolated 0.17 days ( 1.1 days under the most pessimistic possible data assumptions) owing to false-positive findings. Compared to the status quo, the testing intervention would produce a cost per infection averted of $\$ 5,400$ and a cost per death averted of \$1.1 million. Applying the lowest-available estimate from the recommended range of VSL benchmark values (\$5.3 million), this suggests that the intervention would be an exceptionally good value.

\section{Sensitivity to Behavioral Factors}

Test acceptance and adherence to isolation protocols would greatly influence the magnitude of all estimated outcomes (Figure 1 and Table 2). Under Best Case behavioral assumptions, the testing intervention alone could begin to contain the epidemic; under less favorable behavioral scenarios, the impact of testing on the spread 
of infection would be less pronounced. However, even under the Worst Case behavioral scenario (25\% participation; $25 \%$ isolation of positives; $33 \%$ rate of daily abandonment), more than 900,000 infections could be prevented over 60 days.

Costs too would vary widely depending on behavioral assumptions (Table 2). Greater adherence to program protocols would invariably produce greater overall costs, comprised of higher costs of testing (initial and confirmatory) and higher costs of lost workdays, partially offset by lower costs of inpatient care. But cost-effectiveness ratios (e.g., costs per infection and per death averted, compared to No Testing) would behave more stably. Even under the most pessimistic behavioral assumptions, the incremental cost per death averted (\$3.2 million) would remain below the most stringent recommended benchmark VSL (\$5.3 million).

\section{Sensitivity to Test Frequency}

Figure 2 illustrates the critical role played by test frequency. A test that elicits a poor behavioral response will still prevent a large number of infections, if offered with sufficient frequency. Even under Worst Case behavioral assumptions, for example, cumulative infections could be cut more than $33 \%$ via the daily offer of testing. 


\section{Sensitivity to $\mathbf{R}_{\mathbf{t}}$}

Under all scenarios and testing assumptions, greater epidemic severity (as measured by the reproductive number, $\mathrm{R}_{\mathrm{t}}$ ) would produce more infections, more deaths, and higher costs. It would also engender more favorable results for the testing intervention, as measured by infections averted, by deaths averted, and by cost-effectiveness ratios (Table 3).

\section{Sensitivity to the costs of testing}

With initial and confirmatory test costs set to their base case values ( $\$ 5$ and $\$ 20)$, the intervention had an incremental cost-effectiveness ratio of $\$ 1.1$ million/death averted. Setting testing costs to the lowest $(\$ 1, \$ 10)$ and highest $(\$ 10, \$ 50)$ values in our estimated range yielded ICERs per death averted of $\$ 630,000$ and $\$ 1.8$ million, respectively.

\section{Size and composition of isolated population}

Regardless of the testing protocol, large numbers of people will be required to isolate. In the absence of testing, we expect to observe 21 million person-days spent in isolation, all of them attributable to symptoms and hospitalization (Table 2). Notably, this means that the average individual can expect to lose 0.07 workdays to isolation. Under base case assumptions, testing will increase total days spent in isolation to 77 million (or 0.26 days 
per person). However, only $22 \%$ of those days will be attributable to hospitalization, the remainder being the result of testing ( $11 \%$ true positives; $68 \%$ false positives). Under the most pessimistic possible assumptions (i.e., best-case adherence to isolation protocols coupled with worst-case test performance), the average member of the population can expect to spend 1.1 days in unnecessary isolation (i.e., for a false positive) over the course of the 60-day horizon. 


\section{DISCUSSION}

This model-based analysis finds that a nationwide program of frequent, antigen-based home testing and self-isolation could greatly reduce total infections and mortality at a justifiable cost. We arrive at this conclusion using the methods of cost-effectiveness analysis and assumptions that were chosen with the deliberate intent of portraying all aspects of the intervention - the performance of antigen testing; the behavioral response of individuals to testing and isolation protocols; and the societal willingness to pay to avert untimely deaths - in an unfavorable light. Use of more middle-of-the-road data assumptions would only serve to strengthen our policy conclusion. Our bottom line message: do not let the perfect be the enemy of the good; even a highly imperfect home-based testing program could confer enormous benefit.

With an analysis that uses the entire US population as its target, the numerical results reported here are staggering in their magnitude, sensitive to small changes in the input values, and difficult to digest. Although we have attempted to address this by reporting values on a per capita basis and by conducting extensive sensitivity analysis, we nevertheless urge the reader to focus less on our numerical point estimates and more on the remarkable robustness of our qualitative, policy finding: namely, that a nationwide rollout of frequent, home-based testing and self-isolation is justified on both epidemiological and economic grounds.

In addition to the many limitation surrounding any model-based evaluation, our analysis does not account for the potential benefits of regular, inexpensive, rapid testing in other, more targeted 
settings. Schools, factories, air travel, concerts, recreational sports, large family celebrations, and places of worship might choose to make such testing a pre-requisite of participation. Since a small number of people with COVID-19 account for a high proportion of secondary cases, such a strategy would remove some of the most contagious individuals from crowded settings, eliminating case clusters and preventing super-spreader events. ${ }^{31}$

Some observers have questioned the ability of frequent, rapid, antigen testing to reduce transmission, raising several concerns. ${ }^{9}$ These include the lower sensitivity of antigen testing compared to PCR-testing (raising the risk that infectious people will remain in public on the erroneous belief that they are not infectious), the high number of false-positive tests leading to unnecessary isolation, poor adherence to the recommended testing and isolation recommendations, and the massive expense if testing is broadly applied. We acknowledge these concerns and, wherever possible, we have tried to give them voice by adopting modeling assumptions and input data values that tip the scales against nationwide antigen-based home testing.

The strategy of frequent rapid testing to reduce SARS-CoV-2 transmission and decrease COVD19 cases began generating widespread attention in the popular press and on social media many months ago. ${ }^{32,33}$ Implementation on a population-based level, however, has been limited to date. A program of massive, rapid, antigen testing in Slovakia on consecutive weekends appears to have contributed to a reduction in COVID-19 cases beyond what would have been expected through standard infection control measures. ${ }^{34}$ Initiation of a community-based testing pilot in 
Liverpool was associated with a decline in cases, but it is not clear if this was the result of testing or increased infection-control measures and other restrictions. ${ }^{35}$ Current obstacles to broader use of these tests in the United States include the requirement for a doctor's order for certain tests, limited availability, and continued high prices.

Our findings confirm those of other investigators that home-based rapid testing can have a dramatic effect in reducing transmission and COVID-19 mortality at a justifiable cost, ${ }^{1,32}$ with testing frequency a key component to why this broad testing strategy is so effective. Factors currently in play that could worsen the pandemic - a slow start to roll out of widespread vaccination, "pandemic fatigue" regarding social distancing and mask wearing, and emergence of variants that are more easily transmissible - only underscore the importance of frequent rapid testing as a strategy to reduce the number of new cases. 
medRxiv preprint doi: https://doi.org/10.1101/2021.02.06.21251270; this version posted February 8, 2021. The copyright holder for this preprint (which was not certified by peer review) is the author/funder, who has granted medRxiv a license to display the preprint in perpetuity.

It is made available under a CC-BY-ND 4.0 International license .

\section{REFERENCES}

1. Atkenson A, Droste M, Mina M, Stock J. Economic benefits of COVID-19 screening tests. medRxiv 2020.10.22.20217984; doi:

https://doi.org/10.1101/2020.10.22.20217984

2. Mina MJ, Parker R, Larremore DB. Rethinking Covid-19 test sensitivity - a strategy

for containment. N Engl J Med. 2020;383:e120. [PMID: 32997903]

https://doi.org/10.1056/NEJMp2025631

3. Rapid Tests. Expert Letter. 15 December 2020. Accessed at Www.rapidtests.org/expert-letter on 21 January 2021.

4. Toptan T, Eckermann L, Pfeiffer AE, Hoehl S, Ciesek S, Drosten C, Corman VM. Evaluation of a SARS-CoV-2 rapid antigen test: Potential to help reduce community spread? J Clin Virol. 2020;135:104713. [PMID: 33352470] doi:

10.1016/j.jcv.2020.104713

5. McCarthy MW. At-home coronavirus testing: the next game-changer? Expert Rev Mol Diagn. 2021;1-2. [PMID: 33403877] doi: 10.1080/14737159.2021.1873133

6. Mina MJ, Andersen KG. COVID-19 testing: One size does not fit all. Science. 2021;371:126-127. [PMID: 33414210] doi: 10.1126/science.abe9187

7. Silcox C, Anderson D, Zavodszky A, Borre E, Dentzer S, Aspinall MG, et al. A national decision point: Effective testing and screening for Covid-19. Rockeller Foundation. 9 September 2020. Accessed at https:/www.rockefellerfoundation.org/wp-content/uploads/2020/09/A-NationalDecision-Point-Effective-Testing-Screening-for-Covid-19-Full-Report.pdf on 26 January 2021. 
medRxiv preprint doi: https://doi.org/10.1101/2021.02.06.21251270; this version posted February 8, 2021. The copyright holder for this preprint (which was not certified by peer review) is the author/funder, who has granted medRxiv a license to display the preprint in perpetuity.

It is made available under a CC-BY-ND 4.0 International license .

8. Paltiel AD, Walensky, RP. Screening To prevent SARS-CoV-2 outbreaks: Salivabased antigen testing is better than the PCR swab. Health Affairs Blog. 11 September 2020. Accessed at www.healthaffairs.org/do/10.1377/hblog20200909.430047/full/ on 26 January 2021.

9. Pettengill MA, McAdam AJ. Can we test our way out of the COVID-19 pandemic? J Clin Microbiol. 2020;58:e02225-20. [PMID: 32843531] doi: 10.1128/JCM.02225-20

10. U.S. Department of Health and Human Services, Office of the Assistant Secretary for Planning and Evaluation. Guidelines for Regulatory Impact Analysis. 2016. Accessed at www.aspe.hhs.gov/system/files/pdf/242926/HHS_RIAGuidance.pdf on 26 January 2021.

11. Anand S, Montez-Rath M, Han J, Bozeman J, Kerschmann R, Beyer P, et al. Prevalence of SARS-CoV-2 antibodies in a large nationwide sample of patients on dialysis in the USA: a cross-sectional study. Lancet. 2020;396:1335-44. [PMID: 32987007] doi: 10.1016/S0140-6736(20)32009-2

12. Centers for Disease Control and Prevention and the Office of the Assistant Secretary for Preparedness and Response. COVID-19 pandemic planning scenarios. 20 September 2020. Accessed at www.cdc.gov/coronavirus/2019-ncov/hcp/planningscenarios.html on 21 January 2021.

13. He X, Lau EHY, Wu P, et al. Temporal dynamics in viral shedding and transmissibility of COVID-19. Nat Med. 2020;26:672-675. [PMID: 32296168] doi: $10.1038 / \mathrm{s} 41591-020-0869-5$ 
medRxiv preprint doi: https://doi.org/10.1101/2021.02.06.21251270; this version posted February 8, 2021. The copyright holder for this preprint (which was not certified by peer review) is the author/funder, who has granted medRxiv a license to display the preprint in perpetuity.

It is made available under a CC-BY-ND 4.0 International license .

14. Wang F, Qu M, Zhou X, Zhao K, Lai C, Tang Q, et al. The timeline and risk factors of clinical progression of COVID- 19 in Shenzhen, China. J Trans1 Med. 2020;18:270. [PMID: 32620125] doi: 10.1186/s12967-020-02423-8

15. Centers for Disease Control and Prevention. Provisional death counts for coronavirus disease 2019 (COVID-19). 24 September 2020. Accessed at https://www.cdc.gov/nchs/nvss/vsrr/covid_weekly/index.htm on 10 October 2020.

16. Wortham JM, Lee JT, Althomsons S, Latash J, Davidson A, Guerra K, et al. Characteristics of persons who died with COVID-19 - United States, February 12May 18, 2020. MMWR Morb Mortal Wkly Rep. 2020;69:923-929. [PMID: 32673298] doi: 10.15585/mmwr.mm6928e1.

17. Feuer W. FDA authorizes Abbott's rapid \$25 Covid test for at-home use. 16 December 2020. Accessed at https://www.cnbc.com/2020/12/16/fda-authorizesabbotts-rapid-25-covid-test-for-at-home-use.html on 29 January 2021.

18. The Global Fund. Price \& Quality Reporting Price Reference Report. 16 April 2020. Accessed at https://public.tableau.com/profile/the.global.fund\#!/vizhome/PQRPricelist_English/Pr iceList on 29 January 2021.

19. The World Bank. GDP per capita (current US\$) - United States. Accessed at www.data.worldbank.org/indicator/NY.GDP.PCAP.CD?locations=US on 25 January 2021.

20. International Monetary Fund. IMF DataMapper, October 2020. GDP per capita, current prices (U.S. dollars per capita). Accessed at www.imf.org/en/Countries/USA\#countrydata on 25 January 2021. 
medRxiv preprint doi: https://doi.org/10.1101/2021.02.06.21251270; this version posted February 8, 2021. The copyright holder for this preprint (which was not certified by peer review) is the author/funder, who has granted medRxiv a license to display the preprint in perpetuity.

It is made available under a CC-BY-ND 4.0 International license .

21. Lieberman JA, Pepper G, Naccache SN, et al. Comparison of commercially available and laboratory developed assays for in vitro detection of SARS-CoV-2 in clinical laboratories. J Clin Microbiol. 2020;58:e00821-20. [PMID: 32350048] doi:

10.1128/JCM.00821-20

22. Pray IW, Ford L, Cole D, Lee C, Bigouette JP, Abedi GR, et al. Performance of an antigen-based test for asymptomatic and symptomatic SARS-CoV-2 testing at two university campuses - Wisconsin, September-October 2020. MMWR Morb Mortal Wkly Rep. 2021;69:1642-1647. [PMID: 33382679] doi:

10.15585/mmwr.mm695152a3

23. Pilarowski G, Marquez C, Rubio L, Peng J, Martinez J, Black D, et al. Field performance and public health response using the BinaxNOW TM Rapid SARSCoV-2 antigen detection assay during community-based testing. Clin Infect Dis. 2020:ciaa1890. [PMID: 33367619] doi: 10.1093/cid/ciaa1890.

24. Pilarowski G, Lebel P, Sunshine S, Liu J, Crawford E, Marquez C, et al. Performance characteristics of a rapid SARS-CoV-2 antigen detection assay at a public plaza testing site in San Francisco. J Infect Dis. 2021:jiaa802. [PMID: 33394052] doi: 10.1093/infdis/jiaa802

25. Abbot Laboratories. BinaxNOW ${ }^{\mathrm{TM}}$ COVID-19 Ag Card Home Test. 2020. Accessed at http://www.fda.gov/media/141570/download on 26 January 2021.

26. Alemany A, Baró B, Ouchi D, Rodó P, Ubals M, Corbacho-Monné M, et al. Analytical and clinical performance of the panbio COVID-19 antigen-detecting rapid diagnostic test. J Infect. 2021:S0163-4453(21)00004-9. [PMID: 33421447] doi: 10.1016/j.jinf.2020.12.033 
medRxiv preprint doi: https://doi.org/10.1101/2021.02.06.21251270; this version posted February 8, 2021. The copyright holder for this preprint (which was not certified by peer review) is the author/funder, who has granted medRxiv a license to display the preprint in perpetuity.

It is made available under a CC-BY-ND 4.0 International license .

27. Iglói Z, Velzing J, van Beek J, van de Vijver D, Aron G, Ensing R, et al. Clinical evaluation of the Roche/SD Biosensor rapid antigen test with symptomatic, nonhospitalized patients in a municipal health service drive-through testing site. medRxiv 2020.11.18.20234104. doi: https://doi.org/10.1101/2020.11.18.20234104

28. Jefferson T, Spencer EA, Brassey J, Heneghan C. Viral cultures for COVID-19 infectious potential assessment - a systematic review. Clin Infect Dis. 2020:ciaa1764. [PMID: 33270107] doi: 10.1093/cid/ciaa1764

29. Sia SF, Yan LM, Chin AWH, Fung K, Choy KT, Wong AYL, et al. Pathogenesis and transmission of SARS-CoV-2 in golden hamsters. Nature. 2020;583:834-838. [PMID: 32408338] doi: 10.1038/s41586-020-2342-5

30. Komarov A, Kaznadzey A, Li Y, Kireeva M, Mazo I. Dual-Antigen System Allows Elimination of False Positive Results in COVID-19 Serological Testing. Diagnostics. 2021; 11(1):102. https://doi.org/10.3390/diagnostics11010102

31. Adam DC, Wu P, Wong JY, Lau EHY, Tsang TK, Cauchemez S, et al. Clustering and superspreading potential of SARS-CoV-2 infections in Hong Kong. Nat Med. 2020;26:1714-1719. [PMID: 32943787] doi: 10.1038/s41591-020-1092-0

32. Kotlikoff LJ and Mina M. A Cheap, Simple Way to Control the Coronavirus. New York Times. 3 July 2020. Accessed at https://www.nytimes.com/2020/07/03/opinion/coronavirus-tests.html on 29 January 2021.

33. Courage, KH. Rapid \$1 Covid-19 tests exist. Why can’t we get them? Vox. 27 August 2020. Accessed at https://www.vox.com/2020/8/27/21374002/rapid-covid-19test-3m-abbott on 29 January 2021. 
medRxiv preprint doi: https://doi.org/10.1101/2021.02.06.21251270; this version posted February 8, 2021. The copyright holder for this preprint (which was not certified by peer review) is the author/funder, who has granted medRxiv a license to display the preprint in perpetuity. It is made available under a CC-BY-ND 4.0 International license.

34. Pavelka M, Van-Zandvoort K, Abbott S, et al. The effectiveness of populationwide, rapid antigen test based screening in reducing SARS-CoV-2 infection prevalence in Slovakia. 4 December 2020. Accessed at https://www.medrxiv.org/content/10.1101/2020.12.02.20240648v1 on 29 January 2021.

35. Wise J. Covid-19: Concerns persist about purpose, ethics, and effect of rapid testing in Liverpool. BMJ 2020;371:m4690 
Table 1. Behavioral scenarios

\begin{tabular}{|l|c|c|c|}
\hline \multirow{2}{*}{$\%$} & \multicolumn{2}{|c|}{ Testing Behavior Scenario } \\
\cline { 2 - 4 } \% of individuals who make use of tests offered & Best Case & Base Case & Worst Case \\
\hline$\%$ of individuals who self-isolate after a positive test result & 80 & 50 & 50 \\
\hline Daily \% of individuals who abandon isolation & 75 & 25 \\
\hline
\end{tabular}


Table 2. Clinical and Economic Outcomes Under Alternative Testing and Behavior Assumptions

\begin{tabular}{|c|c|c|c|c|}
\hline & No Testing & $\begin{array}{c}\text { Testing: } \\
\text { Behavioral } \\
\text { Worst Case }\end{array}$ & $\begin{array}{l}\text { Testing: } \\
\text { Behavioral } \\
\text { Base Case }\end{array}$ & $\begin{array}{c}\text { Testing: } \\
\text { Behavioral } \\
\text { Best Case }\end{array}$ \\
\hline Total infections (millions) & 14.9 & 14.0 & 11.0 & 5.5 \\
\hline Total Deaths (thousands) & 125 & 120 & 106 & 77 \\
\hline Workdays Lost (total; millions) & 21.4 & 33.1 & 77.4 & 197.6 \\
\hline Workdays Lost (per person) & 0.07 & 0.11 & 0.26 & 0.66 \\
\hline False-Positive Isolation Days (total; millions) & 0 & 10.5 & 52.4 & 172.6 \\
\hline False-Positive Isolation Days (per person) & 0 & 0.04 & 0.17 & 0.58 \\
\hline Total Costs ( $\$$ billions) & 10.35 & 23.88 & 31.86 & 53.37 \\
\hline Infections averted (thousands)* & & 902 & 3,969 & 9,474 \\
\hline Deaths averted* & & 4,205 & 18,945 & 48,130 \\
\hline Incremental costs ( $\$$ billions)* & & 13.52 & 21.50 & 43.01 \\
\hline ICER $^{\dagger}$ (\$/Infections averted) & & 15,000 & 5,400 & 4,500 \\
\hline ICER $^{\dagger}$ (\$/Deaths averted) & & $3,200,000$ & $1,100,000$ & 890,000 \\
\hline \multicolumn{5}{|l|}{ Cumulative Cost Breakdown ( $\$$ billions) } \\
\hline Base test & - & 11.40 & 11.39 & 11.35 \\
\hline Confirmation test & - & 0.16 & 0.61 & 1.41 \\
\hline Inpatient (severe disease) & 3.04 & 2.94 & 2.59 & 1.88 \\
\hline Inpatient (critical disease) & 3.45 & 3.42 & 3.34 & 3.16 \\
\hline Productivity & 3.86 & 5.95 & 13.93 & 35.56 \\
\hline Total & 10.35 & 23.88 & 31.86 & 53.37 \\
\hline \multicolumn{5}{|l|}{ Per Person Cost Breakdown (\$) } \\
\hline Base test & - & 38.00 & 37.97 & 37.84 \\
\hline Confirmation test & - & 0.52 & 2.03 & 4.70 \\
\hline Inpatient (severe disease) & 10.15 & 9.81 & 8.63 & 6.26 \\
\hline Inpatient (critical disease) & 11.49 & 11.41 & 11.13 & 10.54 \\
\hline Productivity & 12.87 & 19.85 & 46.43 & 118.55 \\
\hline Total & 34.51 & 79.59 & 106.19 & 177.89 \\
\hline
\end{tabular}

* Compared to "No Test" scenario; ${ }^{\dagger}$ ICER = incremental cost-effectiveness ratio 
Table 3. Sensitivity of key outcomes to epidemic severity

\begin{tabular}{|c|c|c|c|c|c|c|c|c|}
\hline & Total Cost (\$) & $\begin{array}{c}\text { Total } \\
\text { infections }\end{array}$ & $\begin{array}{c}\text { Total } \\
\text { deaths }\end{array}$ & $\begin{array}{c}\text { Incremental } \\
\operatorname{cost}(\$)^{*}\end{array}$ & $\begin{array}{l}\text { Infections } \\
\text { averted* }\end{array}$ & $\begin{array}{c}\text { Deaths } \\
\text { averted* }\end{array}$ & $\begin{array}{c}\text { ICER }^{\dagger} \\
\text { (\$/Infections } \\
\text { averted) }\end{array}$ & $\begin{array}{c}\text { ICER }^{\dagger} \\
\text { (\$/Deaths } \\
\text { averted) }\end{array}$ \\
\hline \multicolumn{9}{|l|}{$\mathbf{R}_{\mathrm{t}}=\mathbf{0 . 9}$} \\
\hline No Test & $6,423,408,708$ & $3,856,513$ & 65,380 & & & & & \\
\hline Base Case & $28,265,635,826$ & $3,084,105$ & 60,406 & $21,842,227,118$ & 772,408 & 4,974 & 28,278 & $4,390,952$ \\
\hline \multicolumn{9}{|l|}{$R_{t}=1.3$} \\
\hline No Test & $10,351,589,938$ & $14,930,587$ & 124,637 & & & & & \\
\hline Base Case & $31,856,176,855$ & $10,961,643$ & 105,692 & $21,504,586,917$ & $3,968,943$ & 18,945 & 5,418 & $1,135,079$ \\
\hline \multicolumn{9}{|l|}{$\mathbf{R}_{t}=1.7$} \\
\hline No Test & $21,094,569,851$ & $53,002,937$ & 286,342 & & & & & \\
\hline Base Case & $41,662,061,788$ & $38,203,510$ & 227,026 & $20,567,491,937$ & $14,799,426$ & 59,317 & 1,390 & 346,740 \\
\hline \multicolumn{9}{|l|}{$\mathbf{R}_{\mathrm{t}}=2.1$} \\
\hline No Test & $44,402,386,231$ & $131,798,989$ & 638,154 & & & & & \\
\hline Base Case & $64,250,192,494$ & $103,668,349$ & 504,479 & $19,847,806,264$ & $28,130,639$ & 133,675 & 706 & 148,478 \\
\hline
\end{tabular}

* Compared to "No Test" scenario

${ }^{\dagger} \mathrm{ICER}=$ incremental cost-effectiveness ratio 
Figure 1. Daily infections as a function of behavioral scenarios. This figure reports the daily number of infections (vertical axis) under three behavioral scenarios with home-based testing and no home-based testing over a 60-day horizon (horizontal axis). The colored lines denote different testing and behavioral assumptions: no testing (blue); best case (orange); base case (gray); and worst case (yellow).

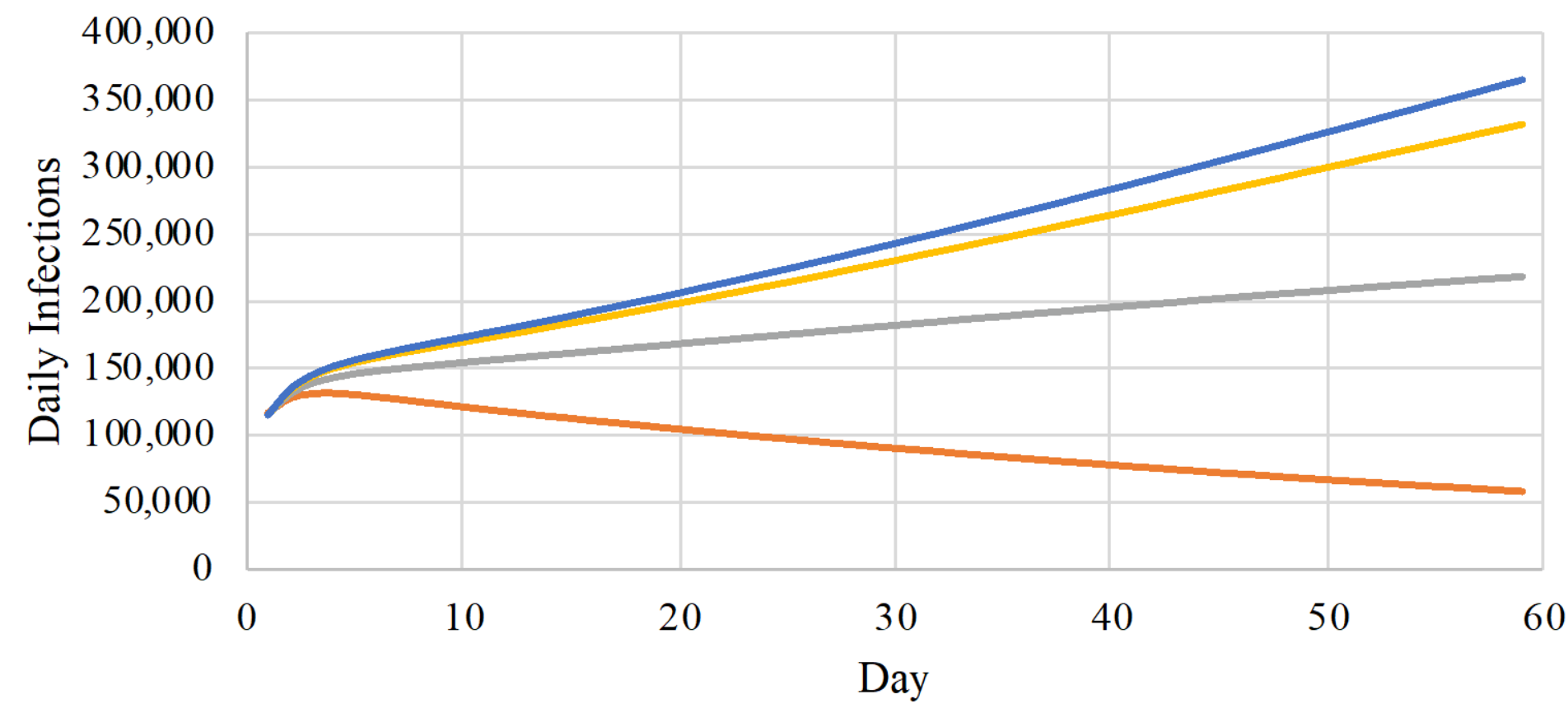

Best Case - Base Case Worst Case $\longrightarrow$ No Test 
Figure 2. Cumulative infections as a function of testing frequency. In this figure, the number of cumulative infections (vertical axis, in millions) is reported for a range of home-based testing frequencies (horizontal axis, ranging from 1 to 15 days between tests). The colored lines denote different testing and behavioral assumptions: no testing (blue); best case (orange); base case (gray); and worst case (yellow).

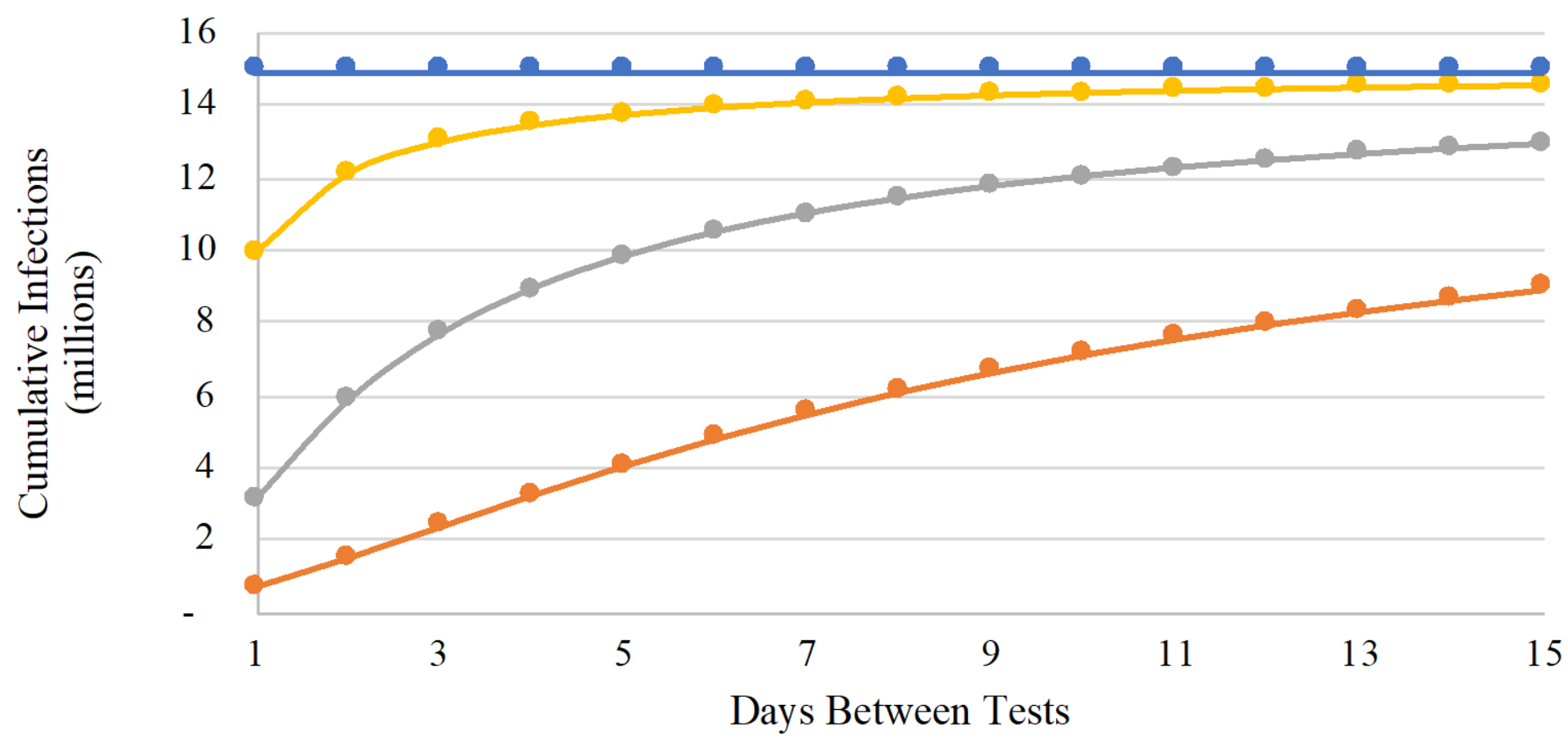

$\longrightarrow$ Best Case $\longrightarrow$ Base Case $\longrightarrow$ Worst Case $\longrightarrow$ Nost 
medRxiv preprint doi: https://doi.org/10.1101/2021.02.06.21251270; this version posted February 8, 2021. The copyright holder for this preprint (which was not certified by peer review) is the author/funder, who has granted medRxiv a license to display the preprint in perpetuity. It is made available under a CC-BY-ND 4.0 International license.

\section{Technical Appendix:}

\section{Clinical and Economic Impact of Widespread Rapid Testing to Decrease}

\section{SARS-CoV-2 Transmission}

A. David Paltiel, $\mathrm{PhD}$

Amy Zheng, BA

Paul E. Sax, MD 
medRxiv preprint doi: https://doi.org/10.1101/2021.02.06.21251270; this version posted February 8, 2021. The copyright holder for this preprint (which was not certified by peer review) is the author/funder, who has granted medRxiv a license to display the preprint in perpetuity.

It is made available under a CC-BY-ND 4.0 International license .

\section{Model Overview}

We developed a dynamic, compartmental model using a modified "susceptible-exposed-infectedrecovered" (or SEIR) framework. The model portrays the epidemiology and natural history of infection in a homogeneous population of at-risk individuals as a sequence of transitions, governed by difference equations, between different health states (or "compartments"). The model diagram (Appendix Figure 1, below) illustrates the modifications we made to the basic SEIR framework:

- Division of the "Infected" state into four distinct sub-compartments, to capture the increasing severity and hospital resource use associated with more advanced COVID-19 disease:

“Asymptomatic," "Mild/Moderate" (outpatient), "Severe" (hospitalized) and "Critical" (hospitalized in an intensive care unit [ICU]). Transitions representing disease progression are denoted in the diagram with green arrows.

- Introduction of a parallel set of states to distinguish between epidemiologically "active" and "removed" individuals. In "active" compartments (on the right side of the diagram), we assumed that individuals interact in ways that permit infectious contact and transmission of SARS-CoV-2; in "removed" compartments (left side), no transmission was possible.

This gave rise to a total of 13 model states:

- U: Uninfected, active

- E: Exposed, asymptomatic, active

- A: Infected, asymptomatic, active

- M: Infected, mild-moderate illness, outpatient, active

- S: Infected, severe illness, inpatient, removed based on hospitalization

- C: Infected, critical illness, inpatient, removed based on hospitalization 
- UFP: Uninfected, removed base on false positive test

- $\quad$ EFP: Exposed, asymptomatic, removed base on false positive test

- $\quad \mathrm{A}_{\mathrm{TP}}$ : Infected, asymptomatic, removed base on true positive test

- Mobs: Infected, mild-moderate illness, outpatient, removed based on observed symptoms

- $\quad \mathrm{M}_{\mathrm{TP}}$ : Infected, mild-moderate illness, outpatient, removed base on true positive test

- R: Recovered, non-infectious, active

- D: Dead, removed

\section{Removal}

We provided two pathways into the "removed" compartments. Individuals with "severe" and "critical" infection were immediately removed by virtue of their advanced COVID-19 symptoms and hospitalization. (We assumed that proper hospital infection control policies would prevent any nosocomial transmission; thus, persons in states S and C do not transmit infection in the model.) We further assumed that that some fraction of individuals with "moderate" symptoms would also elect to self-isolate and therefore enter the "removed" states. (We held this fraction constant at 50\% in the present analysis.)

Testing offered a second avenue to removal. Regular opportunities to be tested for SARS-CoV-2 contagion were offered to persons in the active "uninfected", "exposed", "asymptomatic", and "mild/moderate" compartments. All transitions into the removed compartments arising from positive tests are denoted in the diagram with orange arrows.

- Uninfected individuals receiving a false positive test result moved from the uninfected state $(\mathrm{U})$ to the uninfected/false positive state $\left(\mathrm{U}_{\mathrm{FP}}\right)$. 
- Similarly, individuals exposed to infection (and not yet identifiable as infected via testing) receiving a false positive test result moved from the exposed state (E) to the exposed/false positive state $\left(\mathrm{E}_{\mathrm{FP}}\right)$.

- Asymptomatic individuals receiving a (true) positive test result moved from state (A) to state $\left(\mathrm{A}_{\mathrm{TP}}\right)$.

- Individuals with Mild/Moderate illness (state M) who elected not to self-isolate based upon their symptoms could nonetheless transition to state $\mathrm{M}_{\mathrm{TP}}$ after receiving a (true) positive test result.

Importantly, a positive test result alone was not enough to trigger transition to a removed state. To account for concerns about individual willingness to adhere to testing and isolation protocols, we adopted a highly pessimistic view of the behavioral response to the testing intervention. We assumed that: a) only some fraction (base case $=50 \%$ ) of individuals would elect to make use of the test kits provided to them; b) only some fraction (base case $=50 \%$ ) of individuals receiving a positive test finding would respond by isolating themselves as instructed.

\section{Return to active states}

We provided three pathways from the "removed" compartments back into the "active" population:

- "Abandonment". We assumed that among individuals who initially isolated in response to a positive result, some fraction (base case $=20 \%$ ) would abandon isolation each day and return to the "active" population, against recommended guidance. Because of the short incubation time for COVID-19, we assumed that abandonment of state EFP would 
result in a return to state A. For all other "removed" states, abandonment resulted in a return to the analogous "active" state (i.e., from UFP to U; from ATP to A; and from Mobs and $\mathrm{M}_{\mathrm{TP}}$ to $\left.\mathrm{M}\right)$. All transitions arising from abandonment of isolation are denoted in the diagram with purple arrows.

- Confirmatory testing. We assumed that the shipment of testing kits to households would include a swab for obtaining a PCR test to be self-collected at home and sent to a central laboratory in the case of a positive rapid test result. Individuals whose initially falsepositive result had led them to adhere to recommended isolation protocols (states $U_{F P}$ and $\left.\mathrm{E}_{\mathrm{FP}}\right)$ were assumed to return to the active population after an average 3-day delay. Transitions arising from confirmatory testing are denoted in the diagram with yellow arrows.

- Recovery. We assumed that, in the absence of disease progression, successful isolation of infected persons in states $A_{T P}, M_{O b s}$ and $M_{T P}$ for an average of 10 days would lead to recovery and non-infectious return to the "active" population. (Note: in the absence of disease progression, transition to the Recovered state was also possible for persons in active states $\mathrm{A}$ and $\mathrm{M}$, after an average of 10 days.) Persons in the recovered state $\mathrm{R}$ were assumed to remain active in the transmission pool but are neither able to transmit nor to be infected a second time. All transitions arising from recovery are denoted in the diagram by dotted blue arrows.

\section{Death}

COVID-related mortality was possible from any of states $\mathrm{M}, \mathrm{M}_{\mathrm{Obs}}, \mathrm{M}_{\mathrm{TP}}, \mathrm{S}$, and $\mathrm{C}$. All transitions arising from death are denoted in the diagram by dotted red arrows. 


\section{Parameters}

$\beta_{\mathrm{i}}: \quad$ rate at which infected individuals in state $\mathrm{i}$ contact susceptibles and infect them. This applies to states $\mathrm{A}$ and $\mathrm{M}$.

$\mathrm{p}_{\mathrm{i}}$ : rate of progression from disease state $\mathrm{i}$ to the next stage of disease. This applies to states $\mathrm{E}, \mathrm{A}$, $\mathrm{M}, \mathrm{S}, \mathrm{A}_{\mathrm{TP}}, \mathrm{M}_{\mathrm{Obs}}$, and $\mathrm{M}_{\mathrm{TP}}$.

$\mathrm{r}_{\mathrm{i}}$ : rate at which individuals in state i recover from disease. This applies to states A, M, S, C, ATP, $\mathrm{M}_{\mathrm{Obs}}$, and $\mathrm{M}_{\mathrm{TP}}$.

$\mathrm{m}_{\mathrm{i}}$ : $\quad$ mortality rate for individuals in state $\mathrm{i}$. This applies to states $\mathrm{M}, \mathrm{S}, \mathrm{C}, \mathrm{M}_{\mathrm{obs}}$, and $\mathrm{M}_{\mathrm{TP}}$.

$\mathrm{V}_{\mathrm{i}}$ : testing rate for individuals in state $\mathrm{i}$. This applies to states $\mathrm{U}, \mathrm{E}, \mathrm{A}$, and M. This rate is a multiplicative composite of the base frequency of test offers and the likelihood that an individual in state $\mathrm{i}$ will accept a test offer. (We assumed the same value for individuals in all states.)

$\mathrm{l}_{\mathrm{i}}$ : $\quad$ isolation probability for individuals in state $\mathrm{i}$ who receive a positive test result. This applies to states $\mathrm{U}, \mathrm{E}, \mathrm{A}$, and $\mathrm{M}$. We also apply this probability to persons who develop Mild/Moderate symptoms. (We assumed the same value for individuals in all states.)

$\lambda_{\mathrm{i}}$ : isolation abandonment rate for individuals in state $\mathrm{i}$. This applies to states $\mathrm{U}_{\mathrm{FP}}, \mathrm{E}_{\mathrm{FP}}, \mathrm{A}_{\mathrm{TP}}, \mathrm{M}_{\mathrm{Obs}}$, and $\mathrm{M}_{\mathrm{TP}}$. (We assumed the same value for individuals in all states.)

$\kappa_{\mathrm{i}}$ : false-positive confirmatory test return rate for individuals in state $\mathrm{i}$. This applies to states $\mathrm{U}_{\mathrm{FP}}$ and EFP. (We assumed the same value for individuals in all states.)

Se / Sp: sensitivity and specificity of the home antigen test 
The model uses a cycle time of 1 day. All rates are calculated per daily cycle.

\section{Governing equations}

For ease of computation, we define:

- Weighted force of infection at time t:

$$
\beta^{*}(\mathrm{t})=\beta_{A} \mathrm{~A}(\mathrm{t})+\beta_{M} \mathrm{M}(\mathrm{t})
$$

Active population at time t:

$$
\mathrm{X}(\mathrm{t})=\mathrm{U}(\mathrm{t})+\mathrm{E}(\mathrm{t})+\mathrm{A}(\mathrm{t})+\mathrm{M}(\mathrm{t})+\mathrm{R}(\mathrm{t})
$$

The equations governing transitions from one state to the next are:

- Uninfected $(t+1)=$ Uninfected $(t)-$ New Exposures to E - Isolating False Positives + Returning False Positives (confirmatory test and balking)

$$
\mathrm{U}(\mathrm{t}+1)=\mathrm{U}(\mathrm{t}) \cdot\left[1-\frac{\beta^{*}(\mathrm{t})}{\mathrm{X}(\mathrm{t})}-\mathrm{v} \cdot(1-\mathrm{Sp}) \cdot \mathrm{l}\right]+\mathrm{U}_{F P}(\mathrm{t}) \cdot(\kappa+\lambda)
$$

- $\quad$ Exposed $(t+1)=$ Exposed $(t)-$ New Infections to A - Isolating False Positives + New Exposures from $\mathbf{U}$

$$
\mathrm{E}(\mathrm{t}+1)=\mathrm{E}(\mathrm{t}) \cdot\left[1-p_{E}-\mathrm{v} \cdot(1-\mathrm{Sp}) \cdot \mathrm{t}\right]+U(t) \cdot \frac{\beta^{*}(\mathrm{t})}{\mathrm{X}(\mathrm{t})}
$$


- Asymptomatic $(t+1)=$ Asymptomatic $(t)-$ Progressions to $M-$ Isolating True

Positives - Recoveries + New Infections from E + Returning False Positives from

EFP (confirmatory test and balking) + Balking True Positives from ATP

$\mathrm{A}(\mathrm{t}+1)=\mathrm{A}(\mathrm{t}) \cdot\left(1-p_{A}-\mathrm{v} \cdot \mathrm{Se} \cdot \mathrm{\imath}-r_{A}\right)+\mathrm{E}(\mathrm{t}) \cdot p_{E}+\mathrm{E}_{F P}(\mathrm{t}) \cdot(\kappa+\lambda)+\mathrm{A}_{T P}(\mathrm{t}) \cdot \lambda$

- Mild/Moderate $(t+1)=$ Mild/Moderate $(t)-$ Progressions to S - Recoveries - Deaths

- Isolating True Positives + Progressions from A + Balking True Positives from

Mobs + Balking True Positives from MTP

$$
\begin{gathered}
\mathrm{M}(\mathrm{t}+1)=\mathrm{M}(\mathrm{t}) \cdot\left(1-p_{M}-r_{M}-m_{M}-\mathrm{v} \cdot \mathrm{Se} \cdot \mathrm{t}\right)+\mathrm{A}(\mathrm{t}) \cdot p_{A} \cdot(1-\mathrm{t}) \\
+\left[\mathrm{M}_{O b s}(\mathrm{t})+\mathrm{M}_{T P}(\mathrm{t})\right] \cdot \lambda
\end{gathered}
$$

Only fraction $(1-\imath)$ of individuals progressing to Mild/Moderate symptoms from A will enter state M. The other fraction (1) will directly self-isolate to state $\mathrm{M}_{\mathrm{Obs}}$ based on their observed symptoms.

- Severe $(t+1)=$ Severe $(t)-$ Progressions to $C-$ Recoveries - Deaths + Progressions from M, Mobs, and MTP

$$
\mathrm{S}(\mathrm{t}+1)=\mathrm{S}(\mathrm{t}) \cdot\left(1-p_{S}-r_{S}-m_{S}\right)+\left[\mathrm{M}(\mathrm{t})+\mathrm{M}_{O b S}(\mathrm{t})+\mathrm{M}_{T P}(\mathrm{t})\right] \cdot p_{M}
$$

- Critical $(t+1)=$ Critical $(t)-$ Recoveries - Deaths + Progressions from $S$

$$
\mathrm{C}(\mathrm{t}+1)=\mathrm{C}(\mathrm{t}) \cdot\left(1-r_{C}-m_{C}\right)+\mathrm{S}(\mathrm{t}) \cdot p_{S}
$$


- Uninfected False Positive $(t+1)=$ Uninfected False Positive (t) - Returns to U (confirmatory test and balking) + Isolating False Positives

$$
\mathrm{U}_{F P}(\mathrm{t}+1)=\mathrm{U}_{F P}(\mathrm{t}) \cdot(1-\kappa-\lambda)+\mathrm{U}(\mathrm{t}) \cdot \mathrm{v}(1-\mathrm{Sp}) \mathrm{t}
$$

- Exposed False Positive $(t+1)=$ Exposed False Positive (t) - Returns to A (confirmatory test and balking) + Isolating False Positives

$$
\mathrm{E}_{F P}(t+1)=\mathrm{E}_{F P}(\mathrm{t}) \cdot(1-\kappa-\lambda)+\mathrm{E}(\mathrm{t}) \cdot \mathrm{v}(1-\mathrm{Sp}) \mathrm{t}
$$

- Asymptomatic True Positive $(\mathbf{t}+\mathbf{1})=$ Asymptomatic True Positive ( $\mathbf{t})-$ Progressions to $\mathrm{MTP}_{\mathrm{TP}}$ - Recoveries - Balking returns to A + Isolating True Positives

$$
\mathrm{A}_{T P}(t+1)=\mathrm{A}_{T P}(\mathrm{t}) \cdot\left(1-p_{A}-r_{A}-\lambda\right)+\mathrm{A}(\mathrm{t}) \cdot(\mathrm{v} \cdot \mathrm{Se} \cdot \mathrm{l})
$$

- Mild/Moderate Observed $(\mathrm{t}+\mathbf{1})=$ Mild/Moderate Observed $(\mathrm{t})-$ Progressions to $\mathrm{S}-$ Recoveries - Deaths - Balking returns to $M+$ Isolating based on symptoms from A

$$
\mathrm{M}_{O b s}(t+1)=\mathrm{M}_{O b s}(t) \cdot\left(1-p_{M}-r_{M}-m_{M}-\lambda\right)+A(t) \cdot p_{A} \cdot \imath
$$

Fraction $\mathrm{l}$ of individuals progressing to Mild/Moderate symptoms from A will directly selfisolate to state Mobs based on their observed symptoms.

- Mild/Moderate True Positive (t+1) = Mild/Moderate True Positive (t) - Progressions to $\mathrm{S}$ - Recoveries - Deaths - Balking returns to $\mathrm{M}+$ Progressions from ATP + Isolating True Positives from $M$

$$
\mathrm{M}_{T P}(t+1)=\mathrm{M}_{T P}(t) \cdot\left(1-p_{M}-r_{M}-m_{M}-\lambda\right)
$$




$$
+\mathrm{A}_{T P}(t) \cdot p_{A}+\mathrm{M}(t) \cdot(\mathrm{v} \cdot \mathrm{Se} \cdot \mathrm{l})
$$

- Recovered $(t+1)=$ Recovered $(t)+$ New Recoveries

$$
\mathrm{R}(\mathrm{t}+1)=\mathrm{R}(\mathrm{t})+r_{A}\left[\mathrm{~A}(\mathrm{t})+\mathrm{A}_{T P}(\mathrm{t})\right]+r_{M}\left[\mathrm{M}(\mathrm{t})+\mathrm{M}_{O b s}(\mathrm{t})+\mathrm{M}_{T P}(\mathrm{t})\right]+r_{S} \mathrm{~S}(\mathrm{t})+r_{C} \mathrm{C}(\mathrm{t})
$$

- Deaths $(t+1)=$ Deaths $(t)+$ New Deaths

$$
\mathrm{D}(\mathrm{t}+1)=\mathrm{D}(\mathrm{t})+m_{M} \mathrm{M}(\mathrm{t})+m_{S} \mathrm{~S}(\mathrm{t})+m_{C} \mathrm{C}(\mathrm{t})+m_{M O b S} \mathrm{M}_{O b S}(\mathrm{t})+m_{M T P} \mathrm{M}_{T P}(\mathrm{t})
$$

- Total Population at time $\mathrm{t}=$

$$
\begin{aligned}
\mathrm{U}(\mathrm{t})+\mathrm{E}(\mathrm{t})+\mathrm{A}(\mathrm{t})+\mathrm{M}(\mathrm{t})+\mathrm{S}(\mathrm{t})+\mathrm{C}(\mathrm{t})+\mathrm{U}_{F P}(\mathrm{t})+\mathrm{E}_{F P}(\mathrm{t})+\mathrm{A}_{T P}(\mathrm{t}) \\
+\mathrm{M}_{\text {Obs }}(\mathrm{t})+\mathrm{M}_{T P}(\mathrm{t})+\mathrm{R}(\mathrm{t})+\mathrm{D}(\mathrm{t})=\text { constant }
\end{aligned}
$$

\section{Initial conditions}

We considered the US population ( $\mathrm{N}=300$ million) with the following initial distribution:

$$
\begin{aligned}
& U(0)=270,000(90 \%) \\
& E(0)=600,000(0.2 \%) \\
& A(0)=600,000(0.2 \%) \\
& M(0)=150,000(0.05 \%) \\
& \text { Mobs }(0)=150,000(0.05 \%) \\
& S(0)=150,000(0.05 \%) \\
& C(0)=75,000(0.025 \%) \\
& R(0)=28,275,000(9.425 \%)
\end{aligned}
$$


All other state compartments are empty at time 0 .

\section{Estimating disease progression, recovery, and mortality rates}

In this section, we describe how the parameters used in the governing equations are derived. Unless otherwise noted as an additional assumption, all input values contained in this section are listed and referenced in Appendix Table 1.

\section{- From Exposed state, E}

Individuals spend an average of 3 days in the Exposed state before progressing to Asymptomatic infection. This implies $\mathrm{p}_{\mathrm{E}}=(3 \text { days })^{-1}=0.333$.

\section{- From Asymptomatic state, A}

Assume that $40 \%$ of asymptomatic individuals recover without progressing to Mild/Moderate disease. For the $60 \%$ who do progress to Mild/Moderate disease, the average time spent in the Asymptomatic state is 10 days. This permits us to solve for both progression rate $\mathrm{pA}=(10 \text { days })^{-1}=0.1$ and recovery rate $\mathrm{rA}=(0.4 /(1-0.4))^{*} \mathrm{pA}=0.067$

\section{- From Mild-Moderate state, $M$}

Assume that individuals spend an average of 6 days in state $M$. This gives us $(\mathrm{pM}+\mathrm{mM}+\mathrm{rM})^{-1}$ $=6$. Further assume that $10 \%$ of persons who enter Mild/Moderate illness will eventually progress to Severe illness. This suggests that 
$\mathrm{pM} /(\mathrm{pM}+\mathrm{mM}+\mathrm{rM})=0.1$ and, hence, $\mathrm{pM}=0.1 / 6=0.0167$.

Finally, assume that $1 \%$ of all persons who arrive in state $M$ will die while in that state. This means that $\mathrm{mM} /(\mathrm{pM}+\mathrm{mM}+\mathrm{rM})=1 \%$ and, since we know that $(\mathrm{pM}+\mathrm{mM}+\mathrm{rM})^{-1}=6$, then $\mathrm{mM}=0.01 / 6=0.00167$. This also permits us to solve for $\mathrm{rM}$ : since $\mathrm{rM} /(\mathrm{pM}+\mathrm{mM}+\mathrm{rM})=(1-$ $10 \%-1 \%)=89 \%$, and, since we know that $(\mathrm{pM}+\mathrm{mM}+\mathrm{rM})^{-1}=6$, then $\mathrm{rM}=0.89 / 6=0.1483$.

\section{- From Severe state, $\mathrm{S}$}

Individuals spend an average of 4 days in state $\mathrm{S}$. This gives us $(\mathrm{pS}+\mathrm{mS}+\mathrm{rS})^{-1}=4$. Further assume that $5 \%$ of all persons who arrive in state $\mathrm{S}$ will die in that state. This means that $\mathrm{mS} /(\mathrm{pS}$ $+\mathrm{mS}+\mathrm{rS})=0.05$ and hence $\mathrm{mS}=0.05 / 4=0.0125$.

Now assume that $5 \%$ of persons who enter Severe illness will progress to Critical illness. This suggests that $\mathrm{ps} /(\mathrm{pS}+\mathrm{mS}+\mathrm{rS})=0.05$, implying that $\mathrm{ps}=.05 / 4=0.0125$. We can now solve for the proportion of persons in state $\mathrm{S}$ who recover: $\mathrm{rs} /(\mathrm{pS}+\mathrm{mS}+\mathrm{rS})=(1-5 \%-5 \%)=90 \%$ and since $(\mathrm{pS}+\mathrm{mS}+\mathrm{rS})^{-1}=4$, then $\mathrm{rS}=0.9 / 4=0.225$.

\section{- From Critical state, $\mathrm{C}$}

The average time spent in state $\mathrm{C}$ is 14 days. This gives us $(\mathrm{mC}+\mathrm{rC})^{-1}=14$. 
medRxiv preprint doi: https://doi.org/10.1101/2021.02.06.21251270; this version posted February 8, 2021. The copyright holder for this preprint (which was not certified by peer review) is the author/funder, who has granted medRxiv a license to display the preprint in perpetuity.

It is made available under a CC-BY-ND 4.0 International license .

Further, $15 \%$ of all persons who arrive in state $\mathrm{C}$ will die; the other $85 \%$ will recover. This means that $\mathrm{mC} /(\mathrm{mC}+\mathrm{rC})=0.15$ and hence $\mathrm{mC}=0.15 / 14=0.0107$ while $\mathrm{rC} /(\mathrm{mC}+\mathrm{rC})=0.85$ and hence $\mathrm{rC}=0.85 / 14=0.0607$. 


\section{Estimating transmission parameters}

The basic reproduction number $\left(\mathrm{R}_{\mathrm{t}}\right)$ measures the transmission potential of an infectious agent. In the absence of a vaccine, the basic reproduction number associated with this model is given by:

$$
R_{t}=\frac{\beta_{A}}{p_{A}+r_{A}}+\frac{p_{A}}{p_{A}+r_{A}} \cdot \frac{\beta_{M}}{p_{M}+r_{M}+m_{M}}
$$

We have already derived parameters $\mathrm{pA}, \mathrm{rA}, \mathrm{pM}, \mathrm{rM}$, and $\mathrm{mM}$, above. We assumed that asymptomatic persons were five times more likely to transmit infection than persons with mild/moderate infection and hence $\beta_{\mathrm{A}}=5 \beta_{\mathrm{M}}$. We then solved for the values of $\beta_{\mathrm{A}}$ and $\beta_{\mathrm{M}}$ for a range of different reproduction numbers. In particular, for $R_{t}=\{0.9,1.3,1.8 .2 .1\}$, we obtained $\beta_{A}=\{0.14,0.2,0.28,0.33\}$ and $\beta_{M}=$ $\{0.028,0.041,0.057,0.066\}$. 
medRxiv preprint doi: https://doi.org/10.1101/2021.02.06.21251270; this version posted February 8, 2021. The copyright holder for this preprint (which was not certified by peer review) is the author/funder, who has granted medRxiv a license to display the preprint in perpetuity.

\section{It is made available under a CC-BY-ND 4.0 International license .}

\section{Appendix Figure 1: Model Structure}

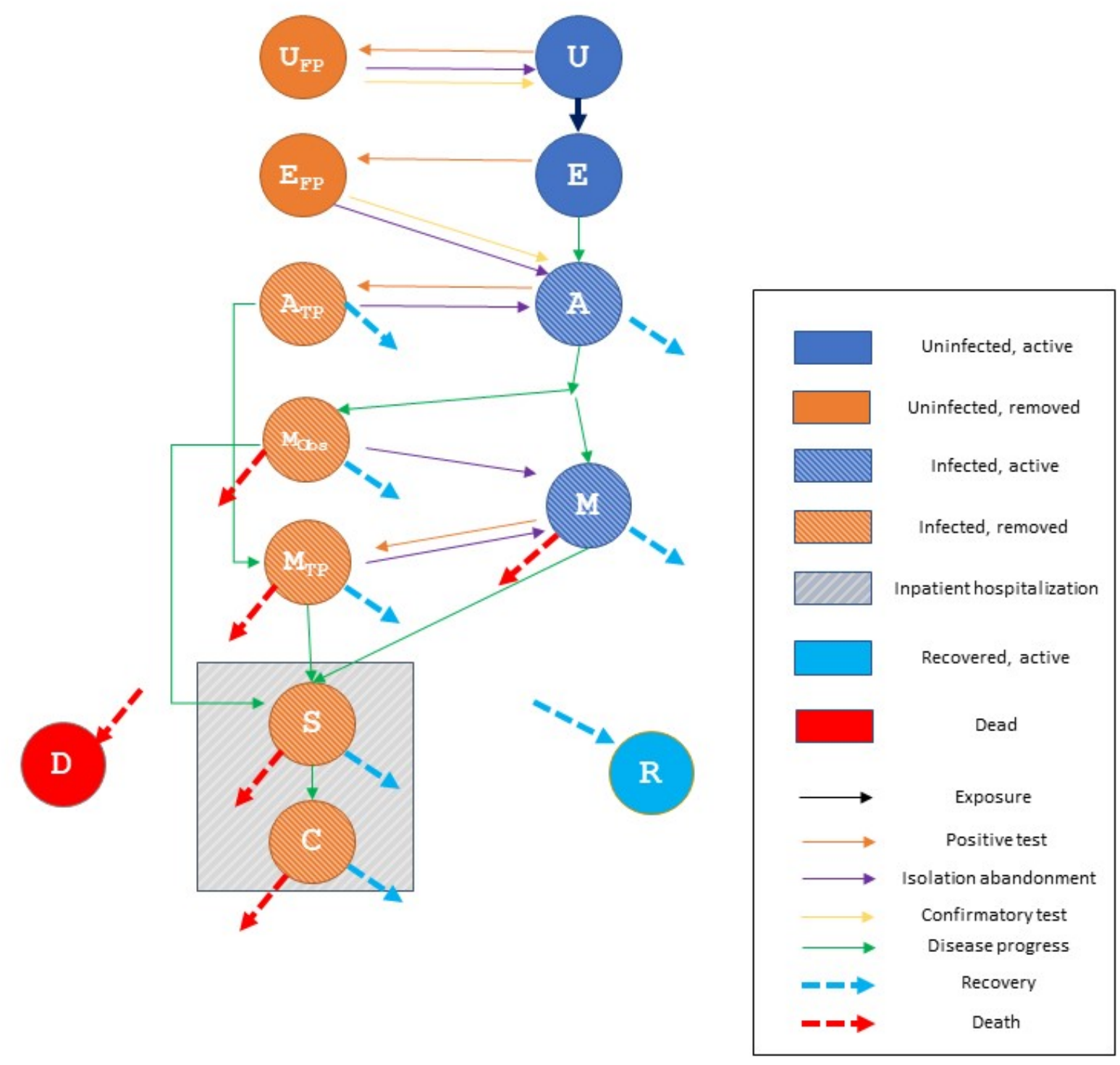


Appendix Table A1. Model parameters and inputs

\begin{tabular}{|c|c|c|}
\hline \multicolumn{2}{|l|}{ Model inputs } & \multirow{2}{*}{$\begin{array}{l}\text { References } \\
\text { Assumption }\end{array}$} \\
\hline Initial population size (n) & $300,000,000$ & \\
\hline Compartments & Initial population (\%) & \\
\hline Non-infected, susceptible & 90.00 & Assumption \\
\hline Exposed & 0.20 & Assumption \\
\hline Infected, asymptomatic & 0.20 & Assumption \\
\hline Infected, symptomatic & 0.05 & Assumption \\
\hline $\begin{array}{l}\text { Infected, symptomatic, in } \\
\text { isolation }\end{array}$ & 0.05 & Assumption \\
\hline Infected, hospitalized & 0.05 & Assumption \\
\hline Infected, ICU & 0.025 & Assumption \\
\hline Recovered & 9.425 & 11 \\
\hline \multicolumn{3}{|c|}{ Average time spent in state (days) } \\
\hline Exposed & 3 & 12 \\
\hline Asymptomatic ** & 6 & 12,13 \\
\hline Mild-Moderate & 6 & 12,14 \\
\hline Severe & 4 & 12,14 \\
\hline Critical & 14 & 12,14 \\
\hline \multicolumn{3}{|c|}{ Likelihood of state-to-state progression (\%) } \\
\hline Exposed to Asymptomatic & 100 & Assumption \\
\hline $\begin{array}{l}\text { Asymptomatic to } \\
\text { Mild/Moderate }\end{array}$ & 60 & 12 \\
\hline Mild-Moderate to Severe & 10 & Assumption \\
\hline Severe to Critical & 5 & Assumption \\
\hline \multicolumn{3}{|c|}{ Recovery (likelihood of recovering from state, \%) } \\
\hline Asymptomatic & 40 & Assumption \\
\hline Mild-Moderate & 89 & Assumption \\
\hline Severe & 90 & Assumption \\
\hline Critical & 85 & Assumption \\
\hline \multicolumn{3}{|c|}{ Mortality (likelihood of death from state, \%) } \\
\hline Asymptomatic & 0 & \\
\hline Mild-Moderate & 1 & 15,16 \\
\hline Severe & 5 & Assumption \\
\hline
\end{tabular}




\begin{tabular}{|c|c|c|}
\hline Critical & 15 & Assumption \\
\hline Time horizon (days) & 60 & Assumption \\
\hline \multicolumn{3}{|l|}{ Population epidemiology } \\
\hline $\begin{array}{l}\text { Effective reproduction } \\
\text { number, } R_{t}\end{array}$ & $1.3(0.9-2.1)$ & Assumption \\
\hline Test characteristics & Base case (range) & \\
\hline Testing frequency (days) & $7(1-15)$ & Assumption \\
\hline Sensitivity (\%) & $80(70-95)$ & Assumption \\
\hline Specificity (\%) & $95(90-99)$ & Assumption \\
\hline $\begin{array}{l}\text { Time to confirmatory test } \\
\text { result return (days) }\end{array}$ & 3 & Assumption \\
\hline Costs (\$) & Base case (range) & \\
\hline Basic test kit & $5(1-10)$ & Assumption \\
\hline Confirmatory test kit & $20(5-50)$ & Assumption \\
\hline Cost of hospitalization & $\$ 1,000 /$ day & Assumption \\
\hline Cost of ICU stay & $\$ 2,500 /$ day & Assumption \\
\hline Productivity loss & $\$ 180 /$ day spent in isolation & 17,18 \\
\hline $\begin{array}{l}\text { Value per statistical life } \\
\text { (VSL) }\end{array}$ & $\$ 5.3-\$ 17.3$ million & 10 \\
\hline
\end{tabular}

